\title{
Evaluation of Balanite aegyptiaca : Leaves, seed kernel cake, fruit coat and flesh as ruminants feed
}

\author{
Shamseldein, H .Ahmed ${ }^{1}$, M. G Morkaz ${ }^{2}$ and Shadia.A., Omer ${ }^{1}$ \\ 1- Department of Biomedical Science, College of Veterinary Medicine. Sudan University of \\ Science and Technology. Sudan. \\ 2- Department of animal physiology, Faculty of Animal Production, University of Geizra. \\ E.mail; shamshahmed@sustech.edu OR shamshahmed@yahoo.com
}

$\underline{\text { Abstract }}$

The study aimed to evaluate the nutritive value of Balanite aegyptiaca leaves, different fruit parts viz. coat, flesh and it's industrial by product seed kernel cake. Chemical composition and in situ dry matter and crude protein degradability were determined. Samples were incubated in rumen for 6, 12, 24, 36, 48 and $72 \mathrm{hrs}$ using three fistulated steers. Significant variation $(\mathrm{P}<0.05)$ were observed in the chemical composition among the leaves, fruit coat, fruit flesh, and seed cake.The seed cake showed the highest crude protein and ash content and lowest crude fibre content. The highest value of nitrogen free extract and ether extract were recorded in the flesh. The fastest dry matter and crude protein degradability were observed in the flesh and the lowest was in the coat. The information provided by this study could be useful in planning for ruminants feeding especially during the dry season.

Key words: Balanite aegyptiaca, Leaves. Coat. Flesh. Seed cake. Degradability

\section{Introduction}

In the Sudan, livestock production is challenged by scarcity of feed, due to seasonal fluctuations in feed quantities, and prices. In addition to that, the concentrated feedstuff produced annually is competed for by humans and livestock. Neglected and underutilized trees often play a vital role in securing food and livestock feed, income generation and energy needs of rural populations, however, Smallholders rely on subsistence farming, with few or no inputs, but trees are usually available and generally provide the sole source of nutrition to the animal (McDermott et al., 1999). Several indigenous and exotic multipurpose trees and shrubs are being evaluated for development of 
integrated crop and livestock agro forestry technologies. ( Duguma et al., 1994).

The Balanites tree can be used as animal feed, the fresh and dried leaves, fruit and sprouts are all eaten by livestock. Balanites kernel cake (BKC) is characterized by high protein $(36.8 \%)$, low crude fibre $(5.9 \%)$ content and non toxic to ruminant and its addition at the rate of $20 \%$, together with $10 \%$ straw, can replace $30 \%$ cotton seed cake in the diet (Khaidir 1983). Balanites aegyptiaca contributes up to $30 \%$ of the dry matter intake of goats in the dry season in Borkinafaso , (Hall and Walker, 1991)- kernel meal, was used for fattening of sheep in the Sudan (Elkhideir, et al., 1983) and in other animals in Senigal ,(Vogt, 1995) and as stock feed in Uganda. (Katende, et al., 1995).

The objective of this study was to evaluate the potentiality of fruits, leaves, coat and kernel cake of B. aegyptiaca trees as ruminant's feed.

\section{Materials and Methods}

\section{Collection and preparation of the samples:-}

Well -ripened fresh fruits of Balanites aegyptiaca were collected from Kordofan State Local Market.

The coat and the flesh of the fruits were removed manually; then the flesh was sun- dried. The leaves were picked from the trees. The seed kernel was obtained by mechanical decortication of the ripened fruit seeds. The kernel cake was obtained by mechanical extraction of the oil from the seeds kernels at an oil mill.

\section{Chemical analysis:-}

Proximate analysis for the different chemical components viz. dry matter (DM), crude protein (C.P), crude fibre (C.F), ether extract (E.E) and ash were determined as described by the AOAC (1990), and the nitrogen free extract was calculated.

\section{Degradability study:}

Three steers were prepared with rumen cannulas, and were fed at a maintenance level a mixture of concentrates and roughages. The dry matter 
and crude protein disappearance in the rumen was determined by in situ polyester bag technique according to Mehrez and Qrskov, (1977). Four gms of the different Balanites aegyptiaca tree parts, were ground to pass;then incubated in the rumen( 2 bags/animal/period/ sample) for 3, 6, 12, 24, 36, 48 and 72 hours.

\section{Calculation of ruminal degradability:}

Dry matter of residues in the bags was calculated as follows:

\section{Incubated sample weight- Weight of residue $\times 100$}

\section{Weight of incubated sample}

Residues from samples after incubation for every period were separately mixed, pooled and made ready for analysis.

Degraded crude protein (CP) from all residues was calculated as follows:

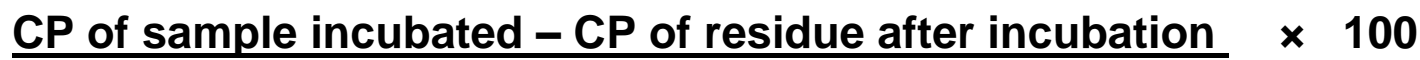
CP of sample incubated

The degradation kinetics of the different parts was described by curve-linear regression of $\mathrm{DM}$ or $\mathrm{CP}$ loss from the bags with time by the equation of Ørskov and McDonald (1979).

$P=a+b(1-\exp -c t)$

Where:

$\mathrm{P}=$ potential degradability $(\%)$.

$\mathrm{a}=$ the soluble and completely degradable substrate (\%)

$\mathrm{b}=$ the insoluble but potentially degradable $(\%)$.

$\mathrm{c}=$ the rate of degradation of $\mathrm{b}(\% / \mathrm{hr})$.

$\mathrm{t}=$ incubation time (hour).

Effective degradability (Ed) of DM and CP was determined, at 0.02, 0.05, and

0.08 ruminal outflow rates, using the equation of Ørskove and McDonald (1979)

Ed. $=\mathrm{a}+(\mathrm{b} \times \mathrm{c} / \mathrm{c}+\mathrm{k})$, where $\mathrm{a}, \mathrm{b}$ and $\mathrm{c}$ are constants defined in equation 1 
$\mathrm{K}=$ small particles out flow rate.

\section{Statistical analysis:-}

The data obtained were subjected to one way analysis of variance to compare the DM and CP degradation kinetics of the different balanites tree parts. Significant differences among the parts were assessed using Least Significant Differences (LSD) test according to Gomez and Gomez, (1984). The Statistical Package for Social Sciences Program (SPSS) was used.

\section{Results}

The chemical composition of the leaves, coat flesh and seed kernel cake of $B$. agyptiaca are shown in Table (1). The highest DM content was shown in the coat and lowest value found in the kernel cake. The crude protein $(\mathrm{CP})$ content was variable $(\mathrm{p}<0.05)$. A high CP content $(47.11 \%)$ was found in the kernel cake, followed by the leaves, coat and the lowest CP was observed in the flesh. The crude fibre (CF) content of the coat recorded the highest value $29.38 \%$, while the kernel cake showed the lowest value $8.54 \%$. The highest Crude fat (CF) content was observed in the flesh $(10.2 \%)$ and the lowest content in the kernel cake (4.5\%). Significant differences, in the ash content among the different parts of $B$. agyptiaca, were observed and the cake showed the highest value. The nitrogen free extract (NFE) content is significantly variable among the different tree parts $(\mathrm{P}<0.05)$, the highest value was observed in the kernel cake $(52.8 \%)$ while the leaves showed the lowest value 
Table (1).

Chemical composition \%of the leaves, coat, and flesh and kernel seed cake of B. agyptiaca (means $\pm \mathrm{SD})$

\begin{tabular}{cc|cc|cc|c|c}
\hline \hline Part & DM\% & EE\% & CP\% & CF\% & Ash\% & NFE\% \\
\hline Leaves & $89.51 \pm 0.06^{\mathrm{c}}$ & $9.04 \pm 0.01^{\mathrm{b}}$ & $35.67 \pm 0.01^{\mathrm{b}}$ & $20.77 \pm 0.01^{\mathrm{b}}$ & $2.60 \pm 0.02^{\mathrm{b}}$ & $21.43 \pm 0.04^{\mathrm{d}}$ \\
Coat & $96.05 \pm 0.07^{\mathrm{a}}$ & $2.15 \pm 0.07^{\mathrm{d}}$ & $12.77 \pm 0.01^{\mathrm{c}}$ & $29.38 \pm 0.02^{\mathrm{a}}$ & $3.00 \pm 0.01^{\mathrm{b}}$ & $50.74 \pm 0.01^{\mathrm{b}}$ \\
Flesh & $94.00 \pm 0.01^{\mathrm{b}}$ & $10.20 \pm 0.01^{\mathrm{a}}$ & $10.55 \pm 0.07^{\mathrm{d}}$ & $18.18 \pm 0.01^{\mathrm{c}}$ & $2.25 \pm 0.07^{\mathrm{c}}$ & $52.80 \pm 0.01^{\mathrm{a}}$ \\
K. cake & $88.44 \pm 0.06^{\mathrm{d}}$ & $4.51 \pm 0.01^{\mathrm{c}}$ & $47.11 \pm 0.01^{\mathrm{a}}$ & $8.54 \pm 0.04^{\mathrm{d}}$ & $5.04 \pm 0.01^{\mathrm{a}}$ & $23.24 \pm 0.02^{\mathrm{c}}$ \\
SEM & 1.19 & 1.15 & 5.82 & 1.89 & 1.62 & 10.20 \\
Sig. & $*$ & $*$ & $*$ & $*$ & $*$ & $*$ \\
\hline \hline
\end{tabular}

Means within the same column with different superscripts are significantly different $(\mathrm{P}<0.05)$.

Sig : $\quad$ Significance level $(\mathrm{P}<0.05)$.

SEM: $\quad$ Standard error of means.

SD : Standard deviation.

The degradability parameters for both CP and DM are presented in Tables (2, 3, 4 , 5). DM degradability of B. aegyptiaca different parts increased from $6 \mathrm{hrs}$ incubation time and reached the maximum at $72 \mathrm{hrs}$ incubation time. The DM degradability rate and effective degradability in this study were highest in the flesh and lowest in the coat.

Table (2): In situ dry matter degradability (\%) of leaves, fuits coat and flesh and seed kernel cake of B. agyptiaca (means $\pm \mathrm{SD}$ ).

\begin{tabular}{|c|c|c|c|c|c|c|c|}
\hline $\begin{array}{c}\text { Incubation } \\
\text { time (h) }\end{array}$ & Zero/hrs & $6 \mathrm{hrs}$ & $12 \mathrm{hrs}$ & $24 \mathrm{hrs}$ & $36 \mathrm{hrs}$ & $47 \mathrm{hrs}$ & $72 \mathrm{hrs}$ \\
\hline leaves & $08.36^{\mathrm{d}}$ & $40.21^{\mathrm{d}}$ & $45.95^{\mathrm{c}}$ & $57.88^{\mathrm{c}}$ & $63.85^{\mathrm{c}}$ & $67.13^{\mathrm{c}}$ & $70.62^{\mathrm{c}}$ \\
\hline coat & $15.05^{\mathrm{c}}$ & $43.86^{\mathrm{c}}$ & $44.82^{\mathrm{c}}$ & $46.42^{\mathrm{d}}$ & $46.42^{\mathrm{d}}$ & $47.39^{\mathrm{d}}$ & $48.67^{\mathrm{d}}$ \\
\hline flesh & $20.37^{\mathrm{b}}$ & $84.91^{\mathrm{a}}$ & $87.42^{\mathrm{a}}$ & $88.36^{\mathrm{a}}$ & $89.92^{\mathrm{a}}$ & $90.86^{\mathrm{a}}$ & $91.18^{\mathrm{a}}$ \\
\hline kernel cake & $33.90^{\mathrm{a}}$ & $57.78^{\mathrm{b}}$ & $60.14^{\mathrm{b}}$ & $63.97^{\mathrm{b}}$ & $81.37^{\mathrm{b}}$ & $83.13^{\mathrm{b}}$ & $84.60^{\mathrm{b}}$ \\
\hline SEM & 2.84 & 5.29 & 4.59 & 4.62 & 5.05 & 5.02 & 4.92 \\
\hline Sig. level & $*$ & $*$ & $*$ & $*$ & $*$ & $*$ & $*$ \\
\hline
\end{tabular}


Means within the same column with different superscripts are significantly different $(\mathrm{P}<0.05)$.

Sig : $\quad$ Significance level $(\mathrm{P}<0.05)$.

SEM : $\quad$ Standard error of means.

SD : Standard deviation.

Table (3 ) Degradation Kinetics of the dry matter of leaves, coat, flesh and seed kernel cake of B. aegyptiaca (means $\pm \mathrm{SD}$ )

\begin{tabular}{|c|c|c|c|c|c|c|c|}
\hline & a. & b. & c. & pd & $\operatorname{Ed}(0.02)$ & $\operatorname{Ed}(0.05)$ & $\operatorname{Ed}(0.08)$ \\
\hline leaves & $62.70^{\mathrm{a}}$ & $18.66^{\mathrm{b}}$ & $0.04^{\mathrm{a}}$ & $81.36^{\mathrm{b}}$ & $70.76^{\mathrm{c}}$ & $65.46^{\mathrm{c}}$ & $64.93^{\mathrm{c}}$ \\
\hline coat & $61.00^{\mathrm{a}}$ & $18.23^{\mathrm{b}}$ & $0.02^{\mathrm{a}}$ & $79.23^{\mathrm{b}}$ & $62.70^{\mathrm{d}}$ & $62.70^{\mathrm{d}}$ & $62.70^{\mathrm{c}}$ \\
\hline flesh & $62.00^{\mathrm{a}}$ & $36.20^{\mathrm{a}}$ & $0.04^{\mathrm{a}}$ & $98.20^{\mathrm{a}}$ & $95.00^{\mathrm{a}}$ & $92.86^{\mathrm{a}}$ & $91.86^{\mathrm{a}}$ \\
\hline kernel cake & $62.00^{\mathrm{a}}$ & $38.00^{\mathrm{a}}$ & $0.03^{\mathrm{a}}$ & 100 & $84.54^{\mathrm{b}}$ & $73.83^{\mathrm{b}}$ & $69.43^{\mathrm{b}}$ \\
\hline SEM & 0.31 & 3.21 & 0.01 & 3.31 & 9.65 & 9.12 & 8.99 \\
\hline $\begin{array}{c}\text { Significant } \\
\text { level }\end{array}$ & $\mathrm{NS}$ & $*$ & $\mathrm{NS}$ & $*$ & $*$ & $*$ & $*$ \\
\hline
\end{tabular}

$\mathrm{a}, \mathrm{b}, \mathrm{c}$ and $\mathrm{d}:$ means within the same row followed by different superscripts are significantly $(\mathrm{p}<$ $0.05)$ different .

a: washing loss .

b: degradation of water insoluble .

c: rate constant of $b$ function

Pd: potential degradability $(\%)$

Ed: Effective degradability at different and flow rate $(0.02,0.05$ and 0.08$)$.

SEM: standard error of means.

The CP degradation characteristic varied among the different plant fractions. The kernel cake showed the highest soluble fraction (a) .

The flesh showed the highest effective degradability while the coat showed the lowest effective degradability. The (c) value of the kernel cake protein was higher than that of the other parts.

Table (4):Rumen degradation \% of crude protein of leaves, coat (Hull), flesh (Pulp) and kernel seed cake of Balanites aegyptiaca tree.

\begin{tabular}{|l|l|l|l|l|}
\hline & $6 \mathrm{hrs}$ & $12 \mathrm{hrs}$ & $24 \mathrm{hrs}$ & $36 \mathrm{hrs}$ \\
\hline leaves & $47.04^{\mathrm{d}}$ & $52.12^{\mathrm{c}}$ & $65.22^{\mathrm{c}}$ & $72.00^{\mathrm{b}}$ \\
\hline coat & $49.08^{\mathrm{c}}$ & $50.13^{\mathrm{d}}$ & $50.92^{\mathrm{d}}$ & $51.77^{\mathrm{c}}$ \\
\hline flesh & $73.41^{\mathrm{a}}$ & $77.68^{\mathrm{a}}$ & $83.66^{\mathrm{a}}$ & $85.92^{\mathrm{a}}$ \\
\hline kernel cake & $65.42^{\mathrm{b}}$ & $67.82^{\mathrm{b}}$ & $71.99^{\mathrm{b}}$ & $85.74^{\mathrm{a}}$ \\
\hline SEM & 5.26 & 5.13 & 4.67 & 4.65 \\
\hline Sig. level & $*$ & $*$ & $*$ & $*$ \\
\hline
\end{tabular}


Table (5)

Degradation kinetics of crude protein of leaves, coat, flesh and seed kernel cake of Balanites aegyptiaca trees.

\begin{tabular}{|c|c|c|c|c|l|l|l|}
\hline & a. & b. & c. & pd & $\operatorname{Ed}(0.02)$ & $\operatorname{Ed}(0.05)$ & $\operatorname{Ed}(0.08)$ \\
\hline leaves & $38.50^{\mathrm{d}}$ & $57.37^{\mathrm{a}}$ & $0.03^{\mathrm{ab}}$ & $95.87^{\mathrm{a}}$ & $74.43^{\mathrm{b}}$ & $66.33^{\mathrm{b}}$ & $64.03^{\mathrm{b}}$ \\
\hline coat & $48.66^{\mathrm{c}}$ & $51.13^{\mathrm{a}}$ & $0.02^{\mathrm{b}}$ & $99.80^{\mathrm{a}}$ & $62.63^{\mathrm{c}}$ & $62.45^{\mathrm{c}}$ & $62.22^{\mathrm{c}}$ \\
\hline flesh & $63.60^{\mathrm{b}}$ & $51.13^{\mathrm{a}}$ & $0.03^{\mathrm{ab}}$ & $95.90^{\mathrm{a}}$ & $84.10^{\mathrm{a}}$ & $76.87^{\mathrm{a}}$ & $73.27^{\mathrm{a}}$ \\
\hline kernel cake & $66.47^{\mathrm{a}}$ & $32.30^{\mathrm{b}}$ & $0.04^{\mathrm{a}}$ & $88.64^{\mathrm{b}}$ & $83.77^{\mathrm{a}}$ & $78.57^{\mathrm{a}}$ & $75.97^{\mathrm{a}}$ \\
\hline SEM & 3.43 & 4.34 & 0.01 & 1.46 & 2.65 & 2.06 & 1.75 \\
\hline $\begin{array}{c}\text { Significant } \\
\text { level }\end{array}$ & $*$ & $*$ & $*$ & $*$ & $*$ & $*$ & $*$ \\
\hline
\end{tabular}

$\mathrm{a}, \mathrm{b}, \mathrm{c}$ and $\mathrm{d}$ : means within the same row followed by different superscripts are significantly $(\mathrm{p}<$ $0.05)$ different .

a: washing loss .

b: degradation of water insoluble .

c: rate constant of $\mathrm{b}$ function

Pd: potential degradability (\%)

Ed: Effective degradability at different out flow rates (0.02, 0.05and 0.08$)$.

SEM: standard error of means.

\section{Discussion.}

The DM content of Balanites aegyptiaca kernel cake was $88.44 \%$, which is lower than that of groundnut cake (94.4\%), sesame cake (94.6\%), cotton seed cake (95.6\%) and sunflower (94\%) as reported by Afaf and Sulieman (1999).

The DM content of Balanites aegyptiaca leaves was $89.51 \%$ ' this result is similar to that obtained by Ondiek ,et al,.(2010) for Acacia tortilis, (89\%),Acacia nilotica, (89.9\%), and Grewia bicolour, (89.4\%) ; and higher than that reported in the leaves of Balanite aegyptiacaleaves, (86.7\%) (Ondiek, etal, 2010) and Zizyphus abyssinica (75.3\%) (Elamin and Babiker, 2000), and is lower than the DM content for the leaves of Adansonia digitata (93.6 (Ikhimioya, et al, 2005).

Crude protein content of B. aegyptiaca kernel cake was $47.11 \%$, which is comparable to that of sesame seed cake (46.0\%) (Omar, 2002) and higher than that reported in B. aegyptiaca kernel cake ( Elkhidir, et al, 1983), groundnut cake(43.5\%) ,sesame seed cake (41.1\%), cotton seed cake (24.4\%) and sunflower cake (26.9\%) (Afaf and Sulieman, 1999) . 
Crude protein of leaves in this study was $35.67 \%$, this finding was higher than that reported for Acacia tortilis, (11.7\%),Acacia nilotica, (12.1\%), Grewia bicolour, (19.6\%) and B. aegyptiaca leaves (13.7) (Ondiek, et al, 2010) Acacia mellifera, (Elamin and Babiker ,2000), Acacia Senegal and Acacia nilotica (Mahala and Assad 2007).

Crude protein of Balanites aegyptiaca flesh was found to be $10.55 \%$ in this study, which is far higher than the CP of Balanites aegyptiaca flesh reported by Guinand and Lemessa ,(2002).

The CF content of B. aegyptiaca kernel cake is in line with that of sesame seed cake and groundnut cake and lowers than that of cotton seed cake (22\%) and sunflower cake (9.5\%) (Afaf and Sulieman ,.1999).

Crude fat content of $B$. aegyptiaca kernel cake is higher than the crude fat content of sesame seed cake(1.4\%),(Omar, 2002) and lower than that reported by Afaf and Sulieman, (1999) in groundnut cake (7.1.\%), cotton seed cake (7.8 $\%)$ sunflower cake $(13.9 \%)$ and sesame seed cake $(11.9 \%)$. There are clear differences in the nutrient content of kernel cake and other types of cakes; this may be attributed to species differences, treatment of the seeds before oil extraction and/or method of oil extraction.

The variation in the chemical composition of the present work and that of other researchers may be attributed to species differences, the plant parts, the age of plant,(Norton 1994); climatic conditions, the state of hydration (fresh wilted or dry) (Palmer and Schlink,1992) and drying procedure (Dzowela et al., 1995).

DM degradability of all B. aegyptiaca parts increased from 6hrs incubation time and reached the maximum at $72 \mathrm{hrs}$ incubation time. The obtained values were comparable with that reported by, Fekadu and Ledin,. (1997) and Tolera and Sundstol, (1999).

The leaves DM degradability rate was comparable with that reported by, (Ikhimioya et a.l, 2005) in Ficus exasperate leaves. While, Elamin and Babiker (2000) recorded higher values for fractions $a, b, a+b$ and c respectively from Ficus sp, Acacia mellifera and Zizyphus spp leaves. 
The effective degradability of leaves in this study at these three out flow rates $(\mathrm{k}=0.02,0.050 .08)$ agreed with the results obtained by Fekadu and Ledin (1997) and Ikhimioya et al. (2005) in the leaves of Ficus exasperate. Higher effective degradability of leaves at these different flow rate was reported in the leaves of Tectonia grandus, Terminolia catappa and Spondias monbin (Ikhimioya et al ,2005).

The DM degradability of Balanites aegyptiaca kernel cake at different times of incubation in this study, increased from $6 \mathrm{hrs}$ incubation period to $36 \mathrm{hrs}$ and slowed up to $72 \mathrm{hrs}$. This result was similar to that obtained by Nidaa (2008) and Aplang (2008) in groundnut cake and sesame seed cake respectively.

The degradation characteristics of Balanites aegyptiaca kernel cake are comparable with that reported by, Mahala and Assad, (2007), in Fehderbia albida pods; Nidaa (2008) and Aplang (2008) recorded higher values for fractions $\mathrm{a}, \mathrm{b}, \mathrm{a}+\mathrm{b}$ and $\mathrm{c}$ respectively from Sesame meal, groundnut cake and sesame cake respectively, and lower values than that of the present work were reported by Mahala and Assad (2007), in sesame seed cake.

The effective degradability of B. aegyptiaca kernel cake dry matter in this study at the different flow rates $(\mathrm{k}=0.02,0.05$ and 0.08$)$ were $84.54 \%, 73.83 \%$ and $69.43 \%$,respectively, a matter which is similar to the values in sesame seed cake $(85.2,74.8$ and $70.5 \%)$,(Aplang ,.2008) and higher than in groundnut cake (43.69\%, 34.93\% and 29.77\%), (Nidaa.2008).

The crude protein $(\mathrm{CP})$ degradation characteristics varied among the different plant fractions. These accords with the reports of Mahala and Assad (2007) who said that different parts of browse vary in degradation kinetics.

The kernel cake showed the highest soluble fraction (a) and this may be attributed to its low fibre content compared with the coat and leaves.

The coat showed the lowest effective degradability; this may be caused due to their contain high fibre content than the other parts ; this accords with Van soest 
and Wine (1967), who found that the more lignified the forage the lower its degradability will be .

The flesh showed the highest effective degradability and this may be to its high soluble carbohydrates contents.

The (c) value of the kernel cake protein was higher than that of the other parts which showed that the kernel cake protein is more attacked by the rumen microbes than the other parts.

The leaves and coat showed comparable values for (a) and (c) to that reported by Elamin and Babiker, (2000), in zizyphus sp and Acaciad mellifern leaves. Lower values in all CP degradation characteristics than in the leaves of the present work are reported in plantin leaves (11.25) and dry ficus leaves (23), by Sudan and Ikhimioya, et al, (2005)in Nigeria and Elamin and Babiker, (2000), in the Sudan .

The coat of Balanites aegyptiaca showed comparable (a) values to that of mesquite pods (47.6) as reported by Batista, et al (2002), the variation can be attributed to species differences. Lower CP soluble fraction for (a) than that of B.aegiptiaca cake was found in the mustard cake(MC), Groundnut cake (GNC), Cotton seed cake (CSC) and linseeds cake (LSC) as reported by Satoo et al (1993). The previous authors reported higher b and $\mathrm{c}$ values for MC (59.4), GNC (87.54), CSC (56.56) and LSC (90.70) than that of Balanites aegyptiaca kernel cake of the current study.

The variation in the kinetics of $\mathrm{CP}$ degradation of this study and that of the other cakes may be explained by to species variation, methods of oil extraction and stage of plant maturity.

The variation in the degradability kinetics of the different $B$. aegyptiaca parts of this work with those findings of other workers may be attributed to species variation, environmental condition, stage of plant growth and differences in chemical composition.

Although the nylon bag technique was widely used to determine the degradation characteristics in the rumen (Orskov and McDonald 1979), there are many factors which may cause variations between the different research 
laboratories. Example of these factors are sample preparation, washing procedure, fistulated animals etc (Nocek 1988,). Lack of standard of this technique may be responsible for the variation of the present work with those of other workers studies in rumen degradation characteristics.

\section{Acknowledgement}

This work was kindly financed by the Scientific Research Counsel-Sudan University of Science and Technology.

\section{REFERENCES}

Afaf, A.R. M and Sulieman, Y. R., (1999). The nutrient composition of Sudanese feeds. Bulletin III. Central Animal Nutrition Research Laboratory, Kuku - Khartoum North.

AOAC. (1990). Official method of analysis. Association of Official Analytical Chemists. pp.66-88. 15th edition. Washington, DC. USA.

Aplang.M.,(2008). Effect of chemical treatment on crude protein and dry matter degradability of sesame cake in rumen.M.Sc. Thesis, Sudan University of science and technology, Pp16-28. Sudan.

Batista , A . M. Mustafa,A.F. McKinnon, J. J and Kermasha.S.(2002). In situ ruminal and intestinal nutrient digestibilities of mesquite(Prosopis juliflora) pods. Anm fed Sci and tech 100: 107 -112 .

Dzowela, B.H., Hove, L., Topps, J.H. and Mafongoya, P.L., 1995. Nutritional and anti-nutritional characters and rumen degradability of dry matter and nitrogen for some multipurpose tree species with potential for agroforestry in Zimbabwe. Anim. Feed. Sci. Technol. $55,: 207-214$. 
Duguma, B., Tonye, J., Kanmengne, J., Manga, T. and Enoch, T., 1994. Growth of ten multipurpose tree species on acid soils in Sangmelima, Cameroon. Agrofor. Syst. 27, pp. 107-119 .

Elamin, M. E. and Babiker M. A. (2000). The composition and degradation in the rumen of goats of different parts of different forage trees in Gezira(Sudan), U. of K. J Agric. Sci. 8(1).: 120 - 133.

Elkhideir, O. A. Gumaa, A. Y. Fangali, O.A. I. Badir, N. A. (1983). The use of Balanites kernel cake in a diet for fattening sheep ., Anim feed Sci and tech $9: 301-306$.

Fekadu, D. and Ledin,I. (1997) Weight and chemical composition of plant parts of enset (Ensete ventricosum) and the intake and degradability of enset by cattle, Livest. Prod. Sci. $49: 249-257$.

Gomez, K.A., and Gomez, A.A. (1984). Statistical procedure for Agricultural research, 2nd ed. Wily and Sons, Inc.

Guinand, Y. and Dechassa Lemessa. 2002. Ethiopia: Famine Food Guide(http://www.africa.upenn.edu/faminefood/category1.htm: accessed on 27 June 2004).

Hall, J. B. Walker H. D. (1991). Balanites aegyptiaca : a monograph. School of Agriculture and forest Sciences Publication Number: 3. University of Wales, Bangor.

Ikhimioya1, O.A. Isah1, U.J. Ikhatua and M.A. Bamikole (2005). Rumen Degradability of Dry Matter and Crude Protein in Tree Leaves and Crop Residues of Nigeria. Pakistan J. of Nutr $4: 313-320$

Katende, A., Birne, Ann and Tengnas, Bo (1995). Useful trees and shrubs for Uganda. Identification, propagation and management for agriculture and pastoral communities. Kampala and Nairobi. Regional Soil Conservation Unit. RSCU/SIDA Technical Handbook Series 10

Mahala, G. A. and Asaad, S. G., (2007). Effect of heat treatment on Sesame cake protein degradation. J . Anm and Vet Sci $2: 39-42$.

McDermott., J.J. McDermott, T.F. Randolph and S.J. Staal, (1999). The economics of optimal health and productivity in smallholder livestock systems in developing countries, Rev. Sci. Technol. 18 (1999), pp. 399-424. View Record in Scopus | Cited By in Scopus (17).

Mehrez, A. Z. and Qrskov, E. R. (1977). Protein degradation and optimum urea concentration in cereal based diet for sheep. Brit. J . Nutr. 40: 337. 
Nidaa . A. M. S.A. Omer and M. T. Ibrahim., (2008). Effect of chemical and physical treatments on ruminal degradation characteristics of groundnut (Arachis hypogaeal) cake.Vet. Med .J ,54: no 119.

Nocek, J.E., and Russell, J.B.(1988). Protein and energy as an integrated system Relation ship of ruminal protein and carbohydrate availability to microbial synthesis and milk production .J .Dairy Sci. 71: 2070-2107.

Norton, B. W. (1994). Tree legumes asdietary supplements for ruminants. In : forage tree legumes in tropical agriculture (R,C Gutteridge and P M. Shelton, editors). CAB International. Walling ford $\mathrm{p}$ 202-215 .

Omar .J. M . A(2002). Effects of feeding different levels of sesame oil cake on performance and digestibility of Awassi lambs. Small Ruminant Research, vol. 46 ( 187 - 190).

Ondiek,J.O,Abdulrazak, S.A, and Njoka,E.N.(2010). Chemical and mineral composition, in-vitro gas production, in - sacco gegradation of selected indigenous Kenyan browse.Livestock research for rural development 22: (2).

Ørskove, E. R, and P. McDonald. (1979). The estimation of protein degradability in the rumen from incubation measurements weighed according to rate of passage. J. Agric. Sci. 92:499-503. Palmer, B. and Schlink, A.C., (1992). The effect of drying on the intake and rate of digestion of the shrub legume Calliandra calothyrsus. Trop. Grassl. 26: 89-93

Palmer, B. and Schlink, A.C., (1992). The effect of drying on the intake and rate of digestion of the shrub legume Calliandra calothyrsus. Trop. Grassl. 26: 89-93

Sato. H., Kudo, Y. and Takeshita, K.,(1993). Blood metabolites mineral levels and enzymatic activities on lactating dairy cows on grazing pasture without concentrate feeding. Jpn.Vet. Sci. 50, p508.

Tolera, A. and F. Sundstol, (1999). Morphological fractions of maize stover harvested at different stages of grain maturity and nutritive value of different fractions of the stover.Anim. Feed Sci. Technol., 81: 1-16.

Van,soest.P.J., and wine,B.A.,(1967). Use of detergents in the analysis of fibre and feeds.Tv. Determintion of plant cell wall components. J.Assoc.Aff. and Chem.50:50.

Vogt, K. (1995). Afield guide to the identification propagation and uses of common trees and shrubs of dry land Sudan. SOS Sahel International (UK).

Zinn, R. A., and N. Owens. 1986. A rapid procedure for purine measurements and its use for estimating net ruminal protein synthesis. Can. J. Anim. Sci. 66:157-166. 
